\title{
Lapurdum
}

LAPURDUM Euskal ikerketen aldizkaria | Revue d'études basques |

Revista de estudios vascos | Basque studies review

$18 \mid 2014$

Numéro XVIII

\section{Basque Words}

José Ignacio Hualde

\section{OpenEdition}

\section{Journals}

Electronic version

URL: http://journals.openedition.org/lapurdum/2472

DOI: 10.4000/lapurdum.2472

ISSN: 1965-0655

Publisher

IKER

\section{Printed version}

Date of publication: 1 October 2014

Number of pages: $7-21$

ISBN: 978-2-86781-409-X

ISSN: $1273-3830$

\section{Electronic reference}

José Ignacio Hualde, « Basque Words », Lapurdum [Online], 18 | 2014, Online since 25 May 2016 connection on 19 April 2019. URL : http://journals.openedition.org/lapurdum/2472 ; DOI : 10.4000/ lapurdum.2472 


\section{Basque Words}

José Ignacio HUALDE

University of Illinois at Urbana-Champaign

\section{Laburpena}

Lan honetan, euskal idazleek, historian zehar, maileguenganako izan dituzten iritziak eta jarrerak azterten ditut, hala nola jarrera horien arrazoiak eta ondorioak. Iritziak asko eta oso desberdinak izan dira: zenbait idazle goiztiarren jarrera irekitik, garbizaletasunaren garaiko maileguen bazterketa orokorrera, geroko garbizalekeriaren aurkako erantzunera, eta azkenean, orain entzuten diren kezka berrietara. Hausnarketa batzuekin bukatzen dut artikulua; hots: zein neurritan euskal hiztegia benetan bereiz daiteke bere hiztunen hiztegi espainol edo frantsesetik euskaldunen elebitasuna orokorra den gaurko egoera honetan?

\section{Abstract}

In this essay, I examine the causes and consequences of the different views and practices of Basque writers regarding loanwords and language mixture in different historical contexts, from the unconcerned attitude of some early writers, to the radical exclusion of loanwords in the age of purism, to later antipuristic reactions, to more recent concerns about word mixing. I end the paper with some reflections regarding the very possibility of having a Basque lexicon that is truly separate from the Spanish or French lexicon of its speakers, in the current situation of general bilingualism on the part of Basque speakers.

Gako hitzak: elebitasuna, hitz mailegatuak, garbizaletasuna, hizkuntz ukipena, euskal hiztegia, euskara

Keywords: bilingualism, loanwords, purism, language contact, Basque lexicon, Basque language 


\section{Basque whalers in Iceland and the Basque nautical pidgin ${ }^{1}$}

In October of the year of 1615 the Basque pilot Martin de Villafranca met a violent death in Iceland, at the hands of a local posse. The life of all the men in his crew ended in the same violent manner. Martin was the captain of a Basque whaling boat that had shipwrecked off the coast of Iceland as the men were preparing to return to the Basque Country. The stranded Basque sailors had been accused of robbery and an order was issued by the governor to capture and kill them. This story is told in much detail in a long poem by Jón Guðmundsson the Learned (lardi) (1574-1658), who seems to have befriended Martin and felt much sorrow about the way Martin and his men were hunted down and killed.

Leaving other aspects of this sad but interesting story aside, one question that arises is how the Basque whalers and the Icelanders communicated. Part of the answer is given by Jón Guðmundsson. In a couple of places in the poem he portrays the Basque Martin speaking in Latin (I add below a Spanish translation provided in Huxley 1987): ${ }^{2}$

(1) From Fjölmódur by Jón Guðmundsson the Learned

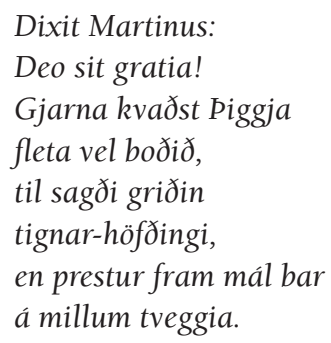

[“Dixit Martinus: 'Deo sit gratia!' De buena gana aceptar esta clemencia quería, esta gracia que el noble magistrado el ofrecía; era el cura mediador".]

In the poem, Jón the Learned also tells us that Martin was singing psalms in Latin as the Icelanders, intent on killing him, approached. Nevertheless, even if Jón the Learned and Martin could communicate in Latin, that would not have been an option for most Basque sailors and Icelandic farmers.

1.- This article started its life as the text of an invited talk at a symposium entitled Transmigrations held at the University of Toronto, Dept. of Spanish and Portuguese, in April 2008. I delivered another version at the Universty of California, Santa Barbara, Dept. of Spanish and Portuguese, in May of the same year with the occasion of a symposium on Basque Studies. This version was available for some time in an online publication of the graduate students of the UCSB Department of Spanish and Portuguese called Tinta, which appears to have been discontinued. I am grateful to Irantzu Epelde for her invitation to publish a revised version of this paper in this special issue of Lapurdum.

2.- The events are also recounted in Hermmansson (1924). A critical edition of Jón Guðmundsson lærdi's poem was published by Pál Eggert Ólason, see Guðmundsson \& Ólason (1916). 
It so happens that we have some direct information on the language used in communication by the Basques in Iceland in the form of two glossaries written in Iceland at the time. These glossaries contain lists of mostly words in Basque (but sometimes in other languages) with their translations in Icelandic. One of the glossaries, however, also contains several sentences, also translated into Icelandic. These documents were first edited and studied by the Dutch linguist Nicholas Deen in 1937 and have been the object of several other studies since then (Hualde 1984, Bakker 1987, Oregi 1987, Bilbao 1991, Miglio 2008). Here are some examples of the sentences in the Basque-Icelandic glossaries. I add English translations instead of the Icelandic of the original:

(2) Basque pidgin

presenta for mi attora 'give me a shirt'

for mi presenta for ju biskusa eta sagarduna 'I will give you cake and cider' cavinit trucka for mi 'I don't buy anything'

for ju mala gissuna 'you are a bad man'

ser travala for ju 'what do you do?'

These sentences are not in Basque, although apparently the Icelandic author of the manuscript thought so. They are in a truly mixed language. The pronouns for $\mathrm{mi}$ and for ju are, of course, English. The words attora 'shirt', biskusa eta sagarduna 'biscuit and cider', gissuna 'man' and ser 'what' are Basque. The verbs presenta, trucka, travala are of Romance origin, although they can also be used in Basque, but lack all inflection that may allow their ascription to a specific language. The word mala 'bad' is Spanish. The word cavinit glossed as 'nothing' is somewhat mysterious. Perhaps it comes from a Low German kein bit niet 'not a bit' (for comparison, Bakker 1987: 11 proposes Dutch kan-me-niet 'I cannot' as its source).

This document offers us evidence that the Basque fishermen of the 17th century had developed a pidgin or simplified trade language to communicate with other people they had to interact with in their travels in the North Atlantic. This code had to fulfill only one goal: to make straightforward communication possible between people who did not share knowledge of another language. Under these circumstances simplification of structure and language mixing was very useful.

But these are special circumstances. Under normal circumstances, language performs several other functions, some of which may, in fact, interfere with straightforward communication. Because of these other functions that are assigned to language, language mixing is often avoided.

In this paper I want to focus on the attitudes towards language mixing that we find in the development of the Basque literary language and the conflicts that arise between the identity-symbolic function that is assigned to this language and the communicative and poetic or artistic goals of writers. In particular, as we will see, at a certain time in history, the Basque language became so imbued with an identitary function that the efforts to make 
it pure and distinct from its neighbors seriously endangered not only its poetic elaboration but also its basic function as a tool for communication. I will finish with some thoughts on how that conflict has been solved or whether, in fact, it is a solvable conflict.

\section{Basque literary language before the rise of purism}

The first book printed in Basque is a book of poems published in 1545 by Bernard Etxepare, a catholic priest. During the 16th and 17th centuries all printed literature in Basque was produced in the northeastern part of the Basque-speaking area, in what is now France. I must add the adjective "printed" to literature for reasons that we will consider below. At this time and in this period, there is a steady production of books in Basque, mostly of a religious nature, but some with literary aspirations.

The first authors to write in Basque do not show any repugnance towards words of Latin and Romance origin. To take an example more or less at random, in the first few lines of Joannes Leizarraga's dedication to the Queen of Navarre, Jeanne of Albret, of his Basque translation of the New Testament, published in 1571, we find the loanwards in (3).

\section{(3) Joannes Leizarraga, Testamentu berria (1571)}

Reguina 'queen', cerbitzari 'servant', obedientac 'obedient', gratiá 'grace', baquea 'peace', desiratzen 'desiring', testamentu 'testament', translatione 'translation' Maiestateari 'to the Majesty', dedicatzera 'to dedicate', ausartu 'dare', mereci 'deserve', accusa 'accuse', etc.

There is nothing surprising about the presence of Romance and Latin words in this text. Since the Basque language has been in contact with Latin and its Romance descendants since Roman times, one would expect that it would have acquired a certain amount of loanwords from this source. It would be surprising if it hadn't.

Joannes Leizarraga refers to his attempts to make himself understood to the widest possible Basque readership, given the obstacles presented by dialectal diversity in Basque. Pedro de Axular, the most accomplished writer of this period, also comments on this issue of achieving wide intelligibility among Basque readers (in the prologue "To the reader" of his book Guero 'Later' [in modern orthography Gero], 1643). The communicative function of language is paramount for these writers, but the poetic function is also given importance. Both Leizarraga and Axular have a very elegant prose. Axular, in particular, employs much word play and stylistic embellishment and his language is still considered a model of literary writing in Basque. Again, something that we don't find in these authors, however, is any attempt to avoid words of Latin or Romance origin.

\section{The age of purism}

If we were to consider any page of some of the books published in Basque at the end of the 19th century and the first half of the 20th century, on the other hand, we would find 
very few recognizable borrowings from Latin or Romance. Michelena (1956), in his review of a Basque translation of St Agustin's Confessions, by Nicolas Ormaetxea "Orixe", points out that even though the book deals at great length with the notion of time, the author manages not to use even once the basic word for 'time' in Basque, denbora, which has the misfortune of deriving from a Latin source, tempora (this is mentioned by Pagola 2005: XXXIII). This is not an exception. In fact, Orixe is not even among the most radical purists and does use some loanwords. To a greater or lesser extent, most of the Basque authors of the period —and perhaps even more the less distinguished ones- avoided loanwords, even those loanwords that had been in the language since Roman times. Villasante (1988) remarks that, even though the word fede 'faith' has a long tradition in Basque, it is not to be found in Azkue's (1905-06) important and massive Basque dictionary. This and many other words are gone. Of course, they are not gone from the oral language of Basque speakers. They are gone from the literary language. I am not talking just about technical terms, I am also talking about basic vocabulary that happens to be of Romance origin.

The leader of this movement to purify the language was Sabino Arana Goiri, the founder of the Basque Nationalist Party and principal expounder of the ideology of Basque nationalism. Arana proposed completely made-up words to replace common words like pertsona 'person', familia 'family', bake 'peace', eliza 'church', aingeru 'angel', paper 'paper' and kale 'street', to name a few, simply because he recognized them as being of foreign origin. In order to maintain the purity of the language, these foreign invaders had to be excluded, even if they had been living in the Basque language since the time of Julius Caesar and the Roman legions.

The consequences of this ideology were dramatic. In its millennia-long contact with Latin and Romance, Basque has acquired a great number of linguistic elements from these neighbors, so that eliminating all Latin and Romance elements from Basque would represent a profound transformation of the language.

In order to replace borrowings, writers of the purist school made use of made-up or rare words that then they needed to explain (in Spanish) to their readers in footnotes to the text. For instance, we find the footnotes listed in (4) in one page of Aunemendiko lorea 'The flower of the Pyrenees', written by Domingo Agirre, perhaps the best Basque novelist of the turn of the century, and first published in 1898.

(4) D. Agirre (1898) Auñemendiko lorea (footnotes in tome 1, p. 10 of 2nd ed.)

\section{1. [Egikera] Erderaz [= 'in Spanish'] estilo 2. Burustalkia - Toca. 3. Margo - Color \\ 4. Leiarra - Cristalino. 5. Liparra - Instante. (LAR.)}

The words in (4) are words that most of Agirre's Basque readers would be expected not to know, because, for the most part, they are neologisms, proposed either by Agirre himself, or by other writers. The last one on this page has the notation "(LAR.)", indicating that it has been taken from the dictionary of Larramendi, a notoriously inventive lexicographer of the 18th century. 
Resurrección María de Azkue, whom I have already mentioned as author of an important dictionary, and who became the first president of the Basque Academy, also includes lists of new coinages, translated into Spanish, in some of his literary works. In the preface to his 1895 play Vizcaytik Bizkaira, we find this:

(5) R. M. Azkue (1895) Vizcaytik Bizkaira

\section{Zer dogu erezi-irautsija? Zer estalkija? Zer atala? Agerraldija zer? Zer iñoix entzun bako beste berba orrek? \\ Ona liburutxu onetan argitaratuko dirian berba barrijak:}

["What is erezi-erautsija? What estalkija? What atala? Agerraldija what? What those other never-heard words? Here are the new words that will be put forth in this little book"]

This is followed by a list of neologisms with their Spanish equivalent: Abizen, 'apellido'; Agerraldi, 'escena'; Agerle, 'actor'; Agirijan, 'en escena'; Asterkari, 'director'; Atal, 'acto'; Batzoki, 'sociedad'; Zenbaki, 'número'; Erabagille, 'Juez'; Erakusle, 'personaje (de Teatro)'; Erezkai, 'letra (para música)'; Erezi-irautsi, 'zarzuela'; Estalki, 'telón'; Irasle, 'escritor'; Iratsi, 'escribir'; Txiñel, 'alguacil'.

One might think that this is not so different from the vocabularies that we find in some of the regionalist novels of the period or a few decades later written in Spanish, such as Rómulo Gallegos' Doña Bárbara. There are however important differences, I believe. In those regionalist novels, the author wishes to capture the real speech of the people being portrayed, which may then require glossing some of the regional terms they use. The gloss, like the text, is in Spanish. In Domingo Agirre's or R. M. Azkue's work, however, it is not the case that anybody's speech is being realistically portrayed, since these are made-up words that are being glossed. The glosses are also often given in a different language from that in which the novel is written. In order to avoid borrowings from Spanish, Agirre, Orixe, Azkue, Arana Goiri and other authors of the period make use of a great profusion of neologisms, which, then, sometimes need to be glossed, in Spanish.

Azkue begins the prologue from which I have just quoted with the words in (6):

\section{(6) Azkue (1895) Vizcaytik Bizkaira}

Irakurlia: eztakit nor axan, ona aixana bai. Gaiztua edo dongia danak, Euskalerri eder onetan jaijua ixanarren, euskerazko asmorik eztau ez ikusi ez entzun nai ixaten.

["Reader: I don't know who you are; but I know you are good. Whoever is bad, even if he or she was born in this beautiful Basque Country, does not want to either see or hear any essays in Basque."]

Azkue, a catholic priest, equates an interest in Basque literature with moral probity. Basque is far from being a morally neutral communication tool for Azkue. It must be a pure 
language in order to reflect the purity of the soul of Basque writers and readers. Inés Pagola (2005: 10, fn.3), in her book Neologismos en la obra de Sabino Arana Goiri, cites from a letter by the champion of all Basque language reformers, Sabino Arana Goiri, written, in Spanish, to one of his friends and dated 28/04/1897:

\section{(7) Sabino Arana Goiri, letter of 28th April 1897 (quoted in Pagola 2005: 10, fn.3)}

Amigo Aingeru: Ahí va la composición musical de Eguzkitza con letra mía. Ya sé que a ésta le pondrás algunos peros. Por ejemplo: que no entenderán deun, ni abes-egin, ni abestu, ni ederrkun, ni orrlei, ni Ludi, ni loraztu, ni siquiera Orrilla y gogo. [...] Pues bien: te advierto que yo no lo corrijo. Quita y pon tú lo que te parezca. Creo, sin embargo, que no hay que corregir lo que no entiendan; ya lo llegarán a entender tarde o temprano. Es seguro que entenderán menos, cuando cantan en español, éstas y semejantes palabras: vergel, a porfía, fragancia, empíreo, etc.

["My dear friend Aingeru: There you have Eguzkitza's musical composition with my lyrics. I know that you will raise some objections. For instance, that people will not understand deun, or abes-egin, or abestu, or ederrkun, or orrlei, or Ludi, or loraztu, and not even Orrilla or gogo. [...] Well, I warn you that I won't correct it. You delete and add whatever you want. I believe, however, that one should not correct what people would not understand. Sooner or later they will understand it. I am sure that they understand even less, when they sing in Spanish, these and similar words: vergel, a porfía, fragancia, empíreo, etc."]

Arana Goiri is, thus, not especially concerned with the intelligibility of his Basque. The important thing is to avoid making it impure with foreign words. It is not clear to what extent Arana Goiri believed in the correctness of the comparison he made in this text between his neologisms and learned words in Spanish. A Spanish speaker who doesn't know the word vergel, may learn it later, in a song, and enrich his or her vocabulary with it. The word vergel is not intended to replace jardín, huerto or any similar word, whereas Arana Goiri created the word Deun 'Saint, holy' in order to replace santu; his neologisms abes-egin 'sing' and abestu are to replace kantatu; orrlei 'green' to replace berde, etc. The word gogo mentioned by Arana Goiri in the text above, is not a neologism; it is a native Basque word meaning "thought, will, intention, memory", but in the poem he is referring to in the letter quoted above he uses it with the meaning of 'spirit' (izpiritu) or 'soul' (arima), two words that he prefers not to use.

A common-sense notion is that language is essentially a tool for communicating between people. That would seem to be the primary function of language. Among turn-ofthe-century Basque intellectuals, however, it is clear that communication was not a primary concern. To quote from Ibon Sarasola's Historia social de la literatura vasca: "En la práctica los intereses del euskera como medio de comunicación quedaron supeditados a su valor dentro de la estrategia global nacionalista, cuyo elemento básico era demostrar que el pueblo vasco era distinto del español" (Sarasola 1976: 143). ["In practice the interests of Basque as a means of communication were subordinated to its value within the global nationalist strategy, whose essential element was demonstrating that the Basque nation was different from the Spanish nation."] 
Arana Goiri's rejection of all foreign words in the Basque language is consistent with his nationalist ideology. For him the Basque people form a separate nation from the Spanish and this should be expressed in a language that is totally different. Words that the Basque language has taken from Spanish over the centuries are alien elements that have to be eliminated. In their zeal to avoid them, Arana Goiri and his followers wrote in a Basque language that needed footnotes in Spanish to be understandable. The Basque language was primarily needed for its symbolic value, as a symbol of a distinct national group. Regarding the Basque language, Arana Goiri was also the receptor of the ideas of past apologists of the Basque language, such as Larramendi and Astarloa, who defended the innate perfection of the Basque language (as Sarasola 1976 and Pagola 2005 point out). The Basque language is (or should be) perfect, and does not need the help of any other languages. This conviction led Arana Goiri and other intellectuals of his generation in their labors of linguistic engineering. Purification was not limited to the lexicon, several proposals for improving Basque morphology and other aspects of the language, based on logical principles, were also advanced in this period. It shouldn't come as a surprise to know that these proposals for making a more perfect Basque language were made, for the most part, in books and articles written in Spanish. It was of only secondary importance that the language that they were perfecting was becoming increasingly different from the spoken language and from the existing literary tradition and thus increasingly opaque, creating serious problems for the communicative function of the language. When these advocates of Basque linguistic purity wanted to make themselves clearly understood, they would write in Spanish.

In the literary domain, a consequence of linguistic purism was a radical break with the existing literary tradition. Literature in Basque had to start anew. All earlier Basque literature was judged to be too contaminated with foreign words to be of any value (Sarasola 1976: 77). Even one of Domingo Agirre's novels was published in a second edition, after the author had died, purified of foreign words (Sarasola 1976: 82-83); that is, with even more lexical censorship than the author had already performed. The elevation of the function of language as an expression of national identity had as its casualties the communicative and poetic functions of the language.

\section{The end of linguistic purism?}

The tide started to turn in the 1950's. The views of those whose primary goal was to make Basque a valid tool of communication for all functions of contemporary society, from the schools and universities, to the mass media, to public administration, to literature, finally prevailed. This new generation saw purism, with the break it represented with the past literary tradition of the language, as a serious obstacle for these goals. In 1959 the Basque Academy made a pronouncement on which words were acceptable in Basque (Euskaltzaindia 1959), a topic where linguistic purism had caused tremendous chaos and insecurity. In the opinion of the Academy, all words that had a tradition in written Basque were to be considered Basque words, regardless of their etymology and regardless of whether or not one could find a "pure" equivalent in Basque. Probably not by chance, this coincided with a rejection of Arana Goiri's 
criterion for determining the "Basqueness" of individuals, which was based on ancestry. ${ }^{3}$ Soon after, under the leadership of the great linguist Luis Michelena (or Koldo Mitxelena, in the form of his name he used when writing in Basque), the Basque Academy established the foundations of modern unified or standard Basque, which has been tremendously successful. Now the community of Basque speakers possesses a modern standard language that has made it possible for speakers of different local dialects to easily communicate with each other, is widely learned as a second language in the Basque Country, and is indeed used for all the purposes that are assigned to any standard language. Being based on the literary tradition, this modern standard also provides ready access to the older literary production. For all of this to happen, the Academy's pronouncement against the extreme purism that demanded the expulsion of all Latin and Romance elements from Basque was a necessary first step.

We may wonder at this point whether the issue has been solved once and for all and this is the end of the story regarding what is and is not a Basque word. The answer is that this is not the case. In 1991, the Basque Academy published another statement on Basque words. Now the Academy's stated preoccupation is that the use of excessive amounts of words of Spanish origin may be causing a fragmentation between a southern dialect influenced by Spanish and a northern dialect influenced by French. In this more recent pronoucement of the Academy "those [words] that a Basque speaker would not be able to understand without knowing Spanish or French are not Basque words at all" (Euskaltzaindia 1991: 446, my translation). The fact is that nowadays virtually all Basque speakers are bilingual in either Spanish or French, but not too many of them are fluent in all three languages. For a Basque speaker to be able to apply the Academy's criterion, he or she would need to know all three languages. It is apparent that what is really behind this voiced concern is a lighter form of purism than Arana Goiri's: If kept unchecked Spanish (or French) influence will endanger not only communication between speakers from both sides of the border, but also the very distinctiveness of the Basque language. The underlying and true cause of the Academy's concern very likely is something that everyone who knows two or more languages is aware of: for a bilingual speaker it is a constant struggle to keep his or her languages apart. For a bilingual writer, it is not easy to find his or her voice in two different languages, a point Gustavo Pérez Firmat eloquently makes in Tongue ties (Pérez Firmat 2003).

When both languages in contact have monolingual speakers, bilingual speakers have strong reasons for keeping the languages apart, including strictly communicative reasons. There is also an external norm - the usage of monolingual speakers- that bilinguals can refer to as a target for their own language use. On the other hand, in a bilingual society, where all speakers of the minority language are also speakers of the majority language - and this is nowadays the case of Basque society - there is no external norm. There are no monolingual speakers with an intuitive sense of what is and is not Basque, to whom bilinguals may refer for

3.- As Michelena pointed out, Arana Goiri's views on this matter are at odds with more traditional criteria, embodied in the Basque language itself, according to which Basque(euskaldun) is s/he who speaks Basque. 
guidance. Avoiding mixing, when speaking the minority language, is also strictly unnecessary, since all speakers also know what you mean if you borrow from the majority language. Clearly, the maintenance and use of the minority language itself is motivated by ideological reasons, not communicative reasons, under these circumstances. It is an act of identity.

\section{Spanglish and euskañol}

One possibility for a bilingual linguistic minority is to embrace language mixing and to accept the mixture of the two languages as a symbol of a new identity for the group. In the case of Spanish in the US, Spanglish, the mixture of Spanish with English, including various types of code switching and code mixing, has acquired this symbolic value for some bilingual speakers and has been used for literary effect by several authors. Ilán Stavans, a wholehearted promoter of Spanglish, has even produced a tongue-in-cheek translation of Don Quijote into Spanglish:

(8) Don Quixote de La Mancha (Ilán Stavans)

\section{Miguel de Cervantes}

First Parte, Chapter Uno

Transladado al Spanglish por Ilán Stavans

In un placete de La Mancha of which nombre no quiero remembrearme, vivía, not so long ago, uno de esos gentlemen who always tienen una lanza in the rack, una buckler antigua, a skinny caballo y un grayhound para el chase. A cazuela with más beef than mutón, carne choppeada para la dinner, un omelet pa' los Sábados, lentil pa' los Viernes, y algún pigeon como delicacy especial pa' los Domingos, consumían tres cuarers de su income. [...]

In the Basque case, code mixing is not openly promoted in any intellectual circles. Nobody praises euskañol. It is interesting to note, however, that we find some of this open attitude towards language mixing in some early literary writing, such as in the work of one of the first Basque writers, Joan Perez de Lazarraga, a man of noble birth from the southern province of Alava, who around 1565, penned a pastoral novel. The novel was never published. The manuscript was discovered only in 2004. Consider for instance the lines in (9). I add a Spanish translation to the side and an English translation at the bottom:

(9) Joan Perez de Lazarraga ( 1565)

Donzellacho linda damea

flordelisea çara çu ene penea dacusun guero

arren berva bat esaçu

Jentil honbre penadua enegaiti cautibua

çure llantu dolorosooc emaiten deustae contentua

\author{
"Doncellita, linda dama" \\ "flor de lis eres tú" \\ "puesto que ves mi pena" \\ "por favor dime una palabra" \\ "Gentil hombre apenado," \\ "por mí, cautivo" \\ "tus llantos dolorosos" \\ "me dan contento"
}


["Young maiden, pretty lady/ you are a fleur-de-lis/ Since you see my pain/ please tell me a word." "Suffering gentleman/ a captive because of me/ your mournful crying/ gives me pleasure."]

Probably nobody would write like this nowadays, except for parody. It is perhaps fortunate that Perez de Lazarraga's work was not rediscovered until a few years ago. Chances are that, had it been found at the beginning of the $20^{\text {th }}$ century, it would have ended up in ashes. Perez de Lazarraga was presumably writing for his friends, who like him, were bilingual and who expressed their identity in both Basque and Castilian Spanish.

The Lazarraga manuscript also includes some poems where Spanish and Latin are mixed. One may conclude that the cultural milieu that this text reflects is one where language mixture is celebrated: Mixing Basque with Spanish and Spanish with Latin is seen as a manifestation of linguistic virtuosity. This couldn't be further away from Arana Goiri's puristic attitude.

We happen to have another document from the same period and the same geographical area: a Dictionarium Linguae Cantabricae written in 1562 by the Italian humanist Niccolò Landucci with the help of some Basque speakers who, like Lazarraga, also appear to have been from Alava, probably from this province's capital, Vitoria (see Michelena's preface to Agud $\&$ Michelena's edition). Landucci's Alavese informants, show the same welcoming attitude towards loanwords from Spanish as we find in parts of the Lazarraga manuscript.

Perhaps one should not be surprised to learn that this dialect no longer exists. The Basque language disappeared from most of Alava, replaced by Spanish monolingualism. We may conclude that both the Ilán Stavans-like open attitude of Lazarraga and his Alavese contemporaries and the other extreme represented by Arana Goiris puristic school appear to lead to the same end result: the language is either abandoned completely or loses all value as an effective tool for communication, being relegated to a symbolic function.

\section{What to do?}

With its more recent proclamation on Basque words (i.e. excessive subordination to Spanish or French is to be avoided), the Academy is, I believe, expressing the sentiments of most Basque speakers. Basque speakers want a Basque language that is alive and a flexible tool for communication, but they also want to keep it distinct, pure, separate from the other languages with which it shares space in their brains and mouths. The question is to what extent this is possible. Even in the work of authors who are very concerned with lexical matters it is common to find entire sentences that faithfully reproduce Spanish phraseology and colloquial expressions. ${ }^{4}$

4.- Of course, the Basque case is not unique. One can see interesting parallels, for instance, in the development of Judeo-Spanish as a journalistic and literary language at the beginning of the 20th century, as discussed by Saul (1983). 
(10) A contemporary example

jarri zuten martziano aurpegia geratu ziztzaidan niri iltzatua
put AUX Martian face remained AUX to-me nailed
Lit. 'the Martian face they put remained nailed to me'
Approx. 'I was struck by the expression of surprise they adopted'

In this example, the literal English translation that I have provided is obviously opaque. On the other hand, this is, of course perfectly coloquial Spanish: "la cara de marciano que pusieron se me quedó a mí clavada', literally. This sort of thing is commonplace in contemporary Basque and unavoidable. I want to make clear that I am not criticizing anybody. I fundamentally agree with the goals of the Basque Academy. My point is that keeping Basque and Spanish apart, without mixture, in the present-day Basque context is rather more difficult than what the members of the Basque Academy may be ready to accept.

A solution that has been proposed to defend the Basque language against the Spanish language's "attack" is better language planning. The Basque Academy should have a normative dictionary, and knowledge of the Academy's dictionary and rules should be spread and reinforced through the school system and the public media.

If we consider languages like English, French or Spanish, it is in fact the case that their users consult normative dictionaries when they have doubts about the correctness of a word and, of course, the school system and public radio and television contribute to the diffusion of the standard variety. But these are also languages that have many monolingual speakers.

If the intention is not only to have a unified standard language, but also one that is distinct from other languages, universal bilingualism makes this an unrealistic goal. It is important to realize that the meaning of a word cannot be captured in a dictionary. The meaning of a word emerges from the discourse contexts where it is used, as the proponents of exemplar theories of language learning have argued. In (10) I glossed, for instance, jarri, as 'put' in the literal English translation. With this I simply mean that in perhaps most contexts jarri would correspond to English put. It would be more exact to gloss jarri with Spanish poner. As we know, there are many contexts where English put is an appropriate translation for Spanish poner, but there are also many other contexts where it is not (se puso enfermo, me puso verde, no te pongas así, poner huevos, no sé que pone aquí, el sol se pone a las siete) and there also many contexts where put cannot be translated with poner. In a language without monolingual speakers, it seems inevitable that its words will tend to become exact equivalents of the words of the majority language, no matter how distinct they are in their sounds. That is, to continue with our example, the tendency will be to make jarri an exact equivalent of poner. In this sense, those purist writers of some generations ago who invented words that they then explained as equivalent to a Spanish word known to the reader, were rather misguided in their means to create a Basque language that would be more distinct from Spanish. In a sense they were inventing Spanish words in Basque clothing. Basque words may keep their visible or audible body but their meaning, their soul will have transmigrated, like we have 
transmigration in the expression quoted above in (10), where we can see the spirit of the Spanish language dressed in Basque forms. This was shown quite a few years ago by Gumperz \& Wilson (1971) for a village in India with three nominally distinct languages.

\section{References}

Agirre, Domingo. 1898. Auñemendiko lorea. Published as a serial novel in Euskalzale starting with issue of January 20. Journal available online in facsimile at http://www.bizkaia. net/kultura/euskara/euskalzale/euskalzale.asp?Tem Codigo=292. 2nd, bilingual ed., with Spanish translation by Ignacio Goikoetxea, 1966, San Sebastián: Auñamendi.

Axular, Pedro. 1643. Guero. Bordeaux: Milanges. Available online at http://klasikoak.armiarma.com/idazlanak/A/AxularGero.htmGero, Critical edition by Luis Villasante with Spanish translation, 1976, Oñati: Jakin, ed. Franciscana Arantzazu.

Azkue, R. M. 1895. Vizcaytik Bizkaira. Bilbao: Astuitar J. Available online at http://klasikoak. armiarma.com/idazlanak/A/AzkueRBizkaira.htm

Azkue, R.M. 1905-06. Diccionario vasco-español-francés. Bilbao. (Reprinted, 1969, Bilbao: La Gran Enciclopedia Vasca; Reprinted, 1984, Bilbao: Euskaltzaindia).

Bakker, Peter. 1987. "A Basque nautical pidgin: A missing link in the history of fu". Journal of Pidgin and Creole Languages 2: 1-30.

Bakker, Peter, Gidor Bilbao, Nicolaas G.H. Deen \& José Ignacio Hualde. 1991. Basque pidgins in Iceland and Canada. Donostia-San Sebastián: Gipuzkoako Foru Aldundia/Diputación Foral de Gipuzkoa. (Supplements of Anuario del Seminario de Filología Vasca 'Julio de Urquijo' 23).

Bilbao, Gidor. 1991. "Glossaria Vasco-Islandica-ren aurkezpen gisakoa". In Bakker et al. 1112 and edition and Basque translation of Deen 1937, same vol., pp. 17-122.

Deen, Nicolaas G. H. 1937. Glossaria duo Vasco-Islandica. Amsterdam: H. J. Paris.

Etxepare [Dechepare], Bernard. 1545. Linguae Vasconum Primitiae. Bordeaux. Available at http://klasikoak.armiarma.com/idazlanak/E/EtxepareBPrimitiae.htm. Critical edition by Patxi Altuna, 1987. Bilbao: Mensajero.

Euskaltzaindia [Basque Academy]. 1959. "Euskaltzaindiaren agiria euskal itzei buruz" [Report of the Basque Academy regarding Basque words]. Euskera 4: 214-215.

Euskaltzaindia. 1991. "Euskaltzaindiaren bigarren agiria euskal itzei buruz" [Second report of the Basque Academy regarding Basque words]. Euskera 36/2: 445-446. 
Gallegos, Rómulo. 1929. Doña Bárbara. Caracas: Araluce.

Gumperz, J. J. \& R. Wilson. 1971. "Convergence and creolization: A case from the IndoAryan-Dravidian border". In Hymes, Dell, ed., Pidginization and creolization of languages, 151-168. London: Cambridge University Press.

Hermannsson, Halldór. 1924. "Jón Guðmundsson and his natural history of Iceland". Islandica: An annual relating to Iceland and the Fiske Icelandic Collection in Cornell University Library, vol. XV. Ithaca, NY: Cornell Univ. Library. Available online in Googlebooks.

Hualde, José I. 1984. "Icelandic Basque Pidgin". Journal of Basque Studies in America 5: 4159. Reprinted in Bakker et al., 123-133.

Huxley, Selma (ed.). 1987. Itsasoa 3: Los vascos en el marco Atlántico Norte. Siglos XVI y XVII. Donostia-San Sebastián: Etor.

Landucci, Niccolò. 1562 [1958]. Dictionarium linguae Cantabricae. Critical ed. by Manuel Agud \& Luis Michelena. San Sebastián: Diputación de Guipúzcoa.

Larramendi, Manuel. 1745. Diccionario trilingüe del castellano, bascuence y latín. DonostiaSan Sebastián: Bartholomé Riesgo y Montero.

Leizarraga, Joanes. 1571. Jesus Christ gure jaunaren Testamentu berria. La Rochelle: Pierre Hautin. Facsimile available at: http://www.euskomedia.org/PDFAnlt/mono/leizarraga/leizarraga_biblia.pdf

Michelena, Luis. 1956. "Agustin Gurenaren Aitorkizunak, Nikolas Ormaetxea "Orixe"-k euskeratua. Itxaropena Argitaldaria. Zarautz". Egan 5/6: 142. Available online at http://andima.armiarma.com/egan/aurki.htm.

Miglio, Viola G. 2008. "Go shag a horse: The $17^{\text {th }}-18^{\text {th }}$ century glossaries revisited". Journal of the North Atlantic 1: 25-36.

Oregi, Eneko. 1987. "Tres glosarios vasco-islandeses del S. XVII". In Huxley, ed., 317-336.

Pagola, Inés. 2005. Neologismos en la obra de Sabino Arana Goiri (= Iker 18). Bilbao: Euskaltzaindia.

Pérez de Lazarraga, Joan. 1564-67. Untitled manuscript. Facsimile and critical edition by Gidor Bilbao, Ricardo Gómez, Joseba A. Lakarra, Julen Manterola, Céline Mounole and Blanca Urgell available at: http:www.lazarraga.com.

Pérez Firmat, Gustavo. 2003. Tongue ties. New York: Palgrave Macmillan. 
Sigursveinsson, Sigur. 1992. "La trágica muerte de Martín de Villafranca en Islandia". In Huxley, ed., 289-294.

Sarasola, Ibon. 1976. Historia social de la literatura vasca, translated by Jesús Antonio Cid. Madrid: Akal. [Originally published in Basque as Euskal literaturaren historia].

Sarasola, Ibon. 1997. Euskara batuaren ajeak. Irun: Alberdania.

Saul, Mahir. 1983. "The modern tongue of the polyglot: Cosmopolitanism and nationalism among the Sepharadim of Istanbul". Anthropological Linguistics 25(3): 326-358.

Stavans, Ilán. "El heart en la palabra": Don Quixote de la Mancha (I). http://www.cuadernoscervantes.com/art_40_quixote.html

Villasante, Luis. 1988. Euskararen auziaz. Colección Eleizalde 9. Estella: Gráficas Lizarra. 